\title{
Role of Mining Bees (Hymenoptera: Andrenidae) in Pollination Ecology in India: A Review
}

\begin{abstract}
Mining bees (Andrenidae) are solitary, ground-nesting, smaller to medium in size, mostly found in the temperate agroforestry and arid ecosystems. These bee's builds their nest in soil mounds and burrows in the soil that's why they are called mining bees. These bees are very efficient pollinator in agricultural crops, fruits, fodder, pulses and other economically important plants. Most of the pollinators including mining bees enhance agricultural productivity at a large commercial level and appear in the beginning of the spring season. Due to their hairy body, scopae, smoky wings, with short and spikey tongue and chewing-lapping type of mouthparts, these adaptive structures are very favourable for the pollination. Our review is based on the importance of mining bees and their role in pollination in different agroforestry ecosystem in India. Besides, the literature pertaining to their pollination mechanism and different activities performed by different species of mining bees has been placed in a single roof for further studies. Family Andrenidae is represented by single genus (Andrena) from India and distributed under 54 species. Very elaborate and comprehensive information about mining bees from the region is presented in this paper.
\end{abstract}

Key words: Agroforestry, Ecosystem. Mining bees, Pollination.

Hymenoptera is one of the largest orders of class Insecta under phylum Arthropoda which includes bees, wasp, sawflies and ants, are generally known for their membranous wings and very distinct in appearance from other insects (Aguiar et al., 2013). Order Hymenoptera is highly evolved insect order consists of approximately 1,55,517 species worldwide and Indian region harbors approx. 10605 species (Chandra et al., 2019a, b and Ahmed et al., 2020). Order Hymenoptera is known to have a wide number of species globally and consist of seven families viz. Apidae, Megachilidae, Halictidae, Andrenidae, Melittidae, Colletidae and Stenotritidae.

The Stenotritidae family is not found in India and is restricted to Australia (Michener, 2007). The manuscript is based on the Literature and emphasizing) the role of mining bees in the pollination, their different morphological characters for collecting pollen, efficiency difference in both male and female bees, visiting proficiency per flower, pollen gathering capacity on the body have been broadly classified. Family Andrenidae is represented by 23 subgenera and 54 species from India and 4 subfamilies, 5 genera and 3015 species worldwide (Meena and Dey, 2019a; Ascher and Pickering, 2020).

In 2016 Andrena agilissima (Scopoli,1770) was recorded for the first time after a long time from Punjab state in India (Makkaret al., 2016). Genus Andrena was first described by Fabricius, 1775 and it was $4^{\text {th }}$ genus suggested later Apis Linnaeus, 1758; Eucera Scopoli, 1770 and Nomada Scopoli, 1770 (Fabricius, 1775). Previously 96 subgenera were recorded by Michener under the genus Andrena (Michener, 2007), while 98 subgenera have been listed by Gusenleitner and Schwarz,2002globally. An annotated andupdated checklist of non-Apisbees of the
Desert Regional Centre, Zoological Survey of India, Jodhpur-342 005, Rajasthan, India.

Corresponding Author: Rifat Hussain Raina, Desert Regional Centre, Zoological Survey of India, Jodhpur-342 005, Rajasthan, India. Email: rifat72001@rediffmail.com

How to cite this article: Raina, R.H., Pathak, P., Saddam, B. and Parrey, A.H. (2022). Role of Mining Bees (Hymenoptera: Andrenidae) in Pollination Ecology in India: A Review. Agricultural Reviews. DOI: 10.18805/ag.R-2308.

Submitted: 18-06-2021 Accepted: 01-01-2022 Online: 21-02-2022

genus Andrena (Hymenoptera: Andrenidae) from India has been systematically studied by Meena and Dey, 2019.

BugFans, 2010 reported that mining bees (Andrenidae) are moderate in size and dull in colour and most of the species are recognized by their host plants where they visit. He further stated that these bees play an important role in pollination and adult mining bee feed nectar and deliver nectar and pollen for their larvae. They are considered as "Buzz Pollinators" and produce vibration which helps to release pollen from flowers. (Cane and Buchmann, 1989). Most of the body parts of these bee such as head, thorax and tibia of the hind legs covered with hairy and dense region, which prevent them from cold. Their hairy body is very helpful to enhance their pollination efficiency in both arid and semi- arid ecosystems.

Mining bees mostly prefer some plants for the nectar forage such as apple, pear, sweet cherry, oilseed rape, various species of orchards, blueberry, huckleberry, Nanking cherry, Manchurian apricots, sunflowers and some other fruit trees. (Tepedino et al., 2007 and Mallinger et al., 2018). Species of the plant families such as Asteraceae, 
Role of Mining Bees (Hymenoptera: Andrenidae) in Pollination Ecology in India: A Review.

Brassicaceae, Cornaceae, Cucurbitaceae are the main food plants of the mining bee (Larkin et al., 2008). Most of the bees are solitary and some of communal (Michener, 2000). Genus Andrena is generally recognized by short tongue and making nest in sandy soil. They have diverse colonial organization mainly solitary to pre-social (Giovanetti et al., 2006). Main morphological characteristics are whole-body covered by brown to black with pale hairs and other colours also found in most of the species usually yellow and metallic blue or green colour. Male bees are more slender than female bees and the body length of male bees is mainly extended from 7.5 to $18.2 \mathrm{~mm}$, smaller than female bees in size. Mining bee can be easily recognizing from other small bees due to wide velvety region called "Facial foveae" found between the compound eyes and basal area of the antennal part and also found long spready hairs on the trochanter of the hind leg and they have two antennal sutures which is an important taxonomic attribute of this family (Meena and Dey, 2019b).

Apis and non-apis bees are considered as beneficial insects as compared to other insects and generally known for their pollinating efforts in many cultivated crops and agroforestry ecosystems. Agroforestry aid in ecosystem services and helps for control of soil erosion, production of livestock, conservation of the quality of water and diversification of farming system. Agroforestry also provides useful and marketable products such as fruits, nuts, medicine, wood products at large level (Schoeneberger et al., 2017 and Jose, 2009). About 85\% pollination of the world's flowering plants caused by animals and mostly by the insects (Ollerton et al., 2011). Bees, wasp, flies, beetles, butterflies, moths, some birds and bats are included in cross pollinators and can pollinate most of the flowering plants (Potts et al., 2016).

The study conducted by Herrera, 1995 stated that all pollinators are considered as an obligatory pollinating agent in the cultivated and non-cultivated crops and both biotic and abiotic factors affect the affiliation between plants and animal pollinators. He further studied that biotic factor such as flower structures, blooming period, quantity and quality of flowers, other species interference and abiotic factors such as temperature, solar radiation, wind direction influence the pollination activity (Corbet, 1990). Pollens are the essential source of nutrient and protein using by bees and also used for pollination. Previously various types of methods were studied in bees in relation with pollination ecology and behaviour towards the wide range of flowering plants and majority of the bees collect pollen as a food for their offspring and highly adapted for this out of nature building such as their adapted structures, behaviour and conspicuous appearance helps in collecting pollen (Thorp, 1979). Portman et al., (2019a) classified into two different classes of pollen collection methods generally used by bees; active and identical pollen collection from anther. They further classified active pollen collection into six ways such as scraping, buzzing, rubbing with the abdomen or corbicula, rubbing by face, tapping and rasping etc. The bees in the genus Andrena performs a scraping mechanism for collecting pollen and use hind, middle and fore legs which supports in expanding the petals of the flower to exhibit the anthers from keel-shaped flowers such as Collinsia (Plantaginaceae) and Lupinus (Fabaceae) (Rust and Clement 1977; Wainwright 1978).

Andrena chlorogaster Viereck, 1904 perform pollen gathering mechanisms via biting with the help of mandibles and also perform scraping method by stretching their forelegs and scraping pollen for accumulate near the body. (Portman et al., 2019b).

Various scientists have worked out that buzzing mechanism performed by mining bees is considered as special kind of pollen collecting strategy and the bees are able to make perceptible vibration by using their thoracic flight muscles to generate vibration which help to release pollen from the anthers and released pollen stick to hairs of the bee's body by electrostatic attraction. (Buchmann and Hurley 1978; Corbet et al. 1982; Buchmann 1983; Vaknin et al. 2000).

Cane and Buchmann 1989 explain the "Buzz milking" mechanism in Protandrena mexicanorum (Cockerell) (Andrenidae), in which they buzz anther of Solanum and collects pollen from anther before folding the tips of the anthers. "Buzzing" mechanism helps to generate hidden pollen from anthers in different species of flowering plants. It is common and traditionally accepted but unusual and erratic in mining bees (Andrenidae) (Meidell 1944; Buchmann and Hurley 1978; Buchmann 1983; Houston and Thorp 1984; Cane, 1985; Neff and Simpson 1988; Thorp 2000). Mining bees are efficient pollinators and because of the pollination mechanism and buzz most of the plant families viz., Asteraceae, Cucurbitaceae, Fabaceae, Papaveraceae, Rosaceae and Plantaginaceae. (Heinrich 1976; Buchmann 1985; Bernhardt 1989 and Russell et al. 2017).

The pollen collecting methods in Oxaea sp. of the family Andrenidae in which bee shake their whole body steadily with the flowers to release pollen from anthers of Senna, Physalis sp. and Solanum sp. of the family Solanaceae was keenly observed by Schrottky, 1908 and Teppner, 2018.

Cazier,1974 found that Protoxaea gloriosa Fox, 1893 (Andrenidae) rotate their whole body with trembling and holding anthers of the floral plant with their hind legs and ventral side of the abdomen to expose pollen from flowers and their flowering host plant is Kallstroemia $\mathrm{sp}$. (Zygophyllaceae) (Cazier and Linsley 1974). In Andrena erigeniae Robertson, 1891 use their legs and body to rub from anthers of the Claytonia sp. (Montiaceae) (Davis and LaBerge 1975). Member of the genus Andrena, rub their abdominal part and scopae from anther of the Camissonia (Onagraceae) flowers to exhibit hidden pollen from flowers. (Potman et al., 2019)

Most of the mining bees use facial part of the head to rub from anthers to directly expose pollen grains. Their hairy structure of the different parts of the head such as clypes, frons, etc support in large amount of pollen accumulation 
on the body surface. Mining bee promote nototribic (Stamen and style are earthward side) flowers for the pollination (Müller 1996 and Thorp 2000). Muller coined the term "Rubbing with facial area" to know different types of the pollination mechanisms followed by different insects. (Müller, 1996).

Eickwort, 1977 noticed temporary accumulation technique in Perdita and Macrotera species of the mining bees (Andrenidae). In this mechanism, bees collect pollen by scraping with the mandibles and forelegs which instantly deliver it into the ventral side of the abdomen. When an adequate amount of the pollen is collected on the venter area then it transfers with the help of the midleg to the scopae of the hind legs (Eickwort 1977; Norden et al. 2003 and Portman, 2019c).

Herrera, 1995 made a detail study on pollination dependency on the temperature in Andrena bicolor (Andrenidae) on Narcissus longispathus and foraged only in the daytime with air temperature about $12^{\circ}-13^{\circ} \mathrm{C}$. He further stated that bee's foraging activity and visitation frequency were depending on temperature. At low thoracic temperature $\left(12^{\circ}-31^{\circ} \mathrm{C}\right)$ bees can easily fly and forage on $N$. longispathus. The visitation rate of bees per flower depends on the average temperature of the internal zone of the flower. When the temperature rises their floral visitation, rate decrease after flower basking. Optimum temperature in $N$. longispathus can favour for the long-time foraging activity in Andrena bicolour Fabricius. It is communal species and its visitation rate was about $70-90 \%$ of all visited pollinators on N. longispathus. Female bees of Andrena bicolor were recorded predominantly for the pollination on $N$. longispathus because of their small size. They can easily hide inside the sepalsand petals of the flower while collecting pollen grains. Thus, Andrena bicolor was never seen on other plant species and it can easily spend most of the time inside the perianth of the $N$. longispathus.

Franzen and Larsson, 2007 broadly studied the pollen and reproductive rates in solitary bees, especially in $A$. humilis which is listed as threatened species as per IUCN. $\mathrm{He}$ further studied that population of the species has declined in the western Europe and has recorded 4 major factors from 19 species of mining bees (Andrenidae) (i) amount required of pollen for making one brood cell, (ii) pollen harvesting rate, (iii) pollen- foraging trips and (iv) bee's activity in the nest such as arrival, leaving, digging and compared all the factors. They further observed average pollen foraging trips measured by 5.3 day $^{-1}$ and nest activity was observed by an average of 1 hour 28 minutes per day. An average time for complete one foraging trip was observed by 10.7 minutes and that time bees were extremely active. As a result, found an average of 3.85 pollen foraging trips are required for complete their one brood cell and in favourable condition one bee can complete their 1.37 brood cell in per day. The authors found that $A$. humilis was most active and efficient pollinator of all other mining bees and their pollen foraging trip was about 60 minutes that was much longer than the other bees. They further observed that propagative rate of $A$. humilis was 0.9 offspring make in one day that was very low and the entire life time it can produce less than 10 offspring. Their low propagativerate was the main reason for their population decline in Western Europe.

Guler and Sorkun, 2010 made a comprehensive study on genus Andrena of family Andrenidae. Most of the members are very significant pollinators to fruit trees besides used scopae of the 34 female bees of the genus Andrena. Among all the mining bees Andrena flavipes pollinated 13 families of the fruit trees belonging to families Apiaceae, Lamiaceae, Brassicaceae, Asrteraceae, Fabaceae etc. (Zandigiacomo et al., 2004) and Brassicaceae was observed leading family for the pollen collection. Andrena flavipes is the bivoltine and communal species, it can easily fly at low temperature. $A$. flavipes represent their activity from two generation (i) spring (March to May), (ii) summer (July to Sep).

Tang et al., 2019 studied the difference between male and female mining bees for their pollination efficiency and significant role in pollination ecology. Most of the bees collect pollen from anthers and deliver it to stigmas and also capable for storing it into scope or corbiculae. Thus, the mining bees are considered as most important and efficient pollinators in agroforestry ecosystem. They further stated that if bee collects more pollen from anther and deliver it to less amount on stigma then it will be considered as non-effectual pollinator. The authors select Andrena emeishanica (Andrenidae) to study the foraging behaviour on Epimedium pubescens. As a result, they observed that female bees were more efficient than male bees because female bees have corbicula on its hind leg for pollen collection with hairy region and almost $90 \%$ of the pollen grains were gathered on its hind leg and rest of the pollen grains stick to thorax and abdomen, used for pollination mechanism on stigmas. Male bee collects less amount of pollen from anthers as compare to female bee but deliver it to per visit large quantity on stigmas. The authors have made a detailed study that pollen transport efficiency of male bee was recorded as $48.4 \%$ per visit and concluded that female bee was more efficient pollinator than male bee and their visiting rate was also more than male bee per visit.

Mining bees collect enough amount of pollen from anthers. Female bees favour their nesting in the sandy soil under the bushes. Female bee marks their nest with their secretion which secreted from specific gland. This secreted material helps in removing moisture from the nest and female bee rub their nest with the upper side of the abdomen which makes robust and shining in the nest. The modus operandi (female Mining bee) is to digging an erected tunnel which is sloped and deep. The entry of the nest's diameter is slightly large. Each tunnel has branched chambers. Female bees store their pollen and nectar in the form of balls-like structures in each chamber and it is very favourable for the female bees for laying an egg. When she lays an egg on the food pile chamber gets closed that time. The larvae of the mining bees stay inside the chamber. Larva feed and pupate inside the chamber and turns into an adult. Bee emerges starting the spring season until they live in the 
Role of Mining Bees (Hymenoptera: Andrenidae) in Pollination Ecology in India: A Review.

chambers for a few months. Female bees are not violent and male bees cannot sting (BugFans, 2010).

Genus Andrena is represented by 54 species from Indian subcontinent and covers almost both arid and semiarid ecosystem and most of the species are listed from North-eastern region of India. Genus Andrena represented by 23 subgenera and distributed over 54 species recorded from India viz., Ferozepur (Punjab), Bihar, Shimla, Western ghats, Kashmir, Mussoorie, North India, Central India, Kohtak, Gujrat, Rajasthan, Delhi, Uttarakhand, Ludhiana, Darjeeling, Dras, Kargil, Leh and Western India. (Meena and Dey, 2019).

Paray et al., 2014 studied the pollinators of apple orchards of Kashmir Himalaya and described the role of Andrena patella and Andrena cineraria in pollination ecology of apple under temperate conditions of Kashmir Himalaya.

\section{CONCLUSION}

Pollination is a very significant act does by mining bees with the help of this act plants produce offspring for the next generation. Pollen collection and their transmission from anthers to stamen is a complex process performed by many species of the mining bees. Male mining bee is smaller than female bee, so many researchers agreed that female bee is more efficient pollinator and having highest pollination potential rather than male bee. Male bee is active for a shorter time during the day for collecting nectar from the flowers while female beescollectboth nectar and pollen. Female mining bee consists of many adaptive structures which enhance their pollination efforts in the pollination ecosystem service. Different species of the mining bees perform different types of pollen collecting mechanisms such as buzzing, scraping, rasping, rubbing and these mechanisms help to easily remove pollen from anther and reduce the duration of interaction between bee and anther.

In India most of the bees are facing threats and their diversity is declining progressively which is mainly affected by habitat loss, diseases, pesticides and climate changes. Different types of conservation management strategies shall be applied to enhance the population of mining bees both in the arid and semi-arid ecosystems of Indian sub-continent. The following methods shall be employed in the field of orchards and crops for better pollination such as placement of wooden blocks, stem bundles and soil intervention these methods shall increase the diversity of soil dwelling bees and are essential for the pollination of many food crops. The review highlighted that the different environmental traits, flower-patterned and nesting practise condition of the targeted species needs to be identified. The consequence of the conservation measures has also to be evaluated not for in terms of species diversity, richness and abundance but also in terms of environmental and physical traits.

\section{ACKNOWLEDGEMENT}

The authors are highly grateful to the Director Zoological Survey of India, Kolkata for providing the necessary facilities.
Thanks, are also due to Officer-in-Charge, DRC, ZSI, Jodhpur (Rajasthan) for his benevolent support. Special thanks are due to National Mission on Himalayan Studies (NMHS), Almora, Uttarakhand under MOEF and CC, Govt., of India, New Delhi for providing financial assistance under the project "Documentation, conservation and utilization of indigenous mountain pollinators- with special reference to Himalayan bumblebees".

Conflicts of interest: None.

\section{REFERENCES}

Aguiar, A.P. et al., (2013). Zootaxa. "Order Hymenoptera Linnaeus, 1758. In: Animal Biodiversity: An Outline of Higher- level Classification and survey of Taxonomic Richness (Addenda 2013)": [Zhang, Z.Q. (Ed.)]. 3703: 1-82 doi:10.11646/ zootaxa.3703.1.12. PMID 26146682.

Ahmed, I., Saini, J., Singh, L.R.K., Gupta, D. and Chandra, K. (2020). Fauna of Haryana, State Fauna Series. Zool. Surv. India. 24: 189-220.

Ascher, J.S. and Pickering, J. (2020). Discover life bee species guide and checklist (Hymenoptera: Apoidea: Anthophilia). http://www.discoverlife.org $/ \mathrm{mp} / 20 \mathrm{q}$ ?guide= Apoidea_ species.

Bernhardt, P. (1989). Floral ecology of Australian acacias. In: Advance in legume biology. [Stirton C.H., Zarucchi, J.L. (Eds)], Monographs in Systematic Botany from the Missouri Botanical Garden, St. Louis, MO. 263-282.

Buchmann, S.L. and Hurley, J.P. (1978). A biophysical model for buzz pollination in angiosperm. Journal of Theoretical Biology. 72: 639-657. https://doi.org/10.1016/0022-5193 (78) $90277-1$

Buchmann, S.L. (1983). Buzz Pollination in Angiosperm. In: Handbook of Experimental Pollination Biology. [Jones, C.E., Little, R.J. (Eds)], Van Nostrand Reinhold Co., New York, 73-113.

Buchmann, S.L. (1985). Bees use vibration to aid pollen collection from non-poricidal flowers. Journal of the Kansas Entomological Society. 58: 517-525. https://www.jstor.org/ stable/25084671.

Buchmann, S.L. and Cane, J.H. (1989). Bees assess pollen return while sonicating Solanum flowers. Oecologia. 81: 289294. https://doi.org/10.1007/BF00377073.

BugFans. (2010). Mining Bee (Family Andrenidae). Link- https:// uwm.edu/field-station/mining-bee/.

Cazier, M.A. and Linsley, E.G. (1974). Foraging behaviour of some bees and wasps at Kallstroemia grandiflora flowers in Southern Arizona and New Mexico. American Museum Novitates 2546: 1-20. http://hdl.handle.net/2246/5450.

Cane, J.H. (1985). A promenade through eusocial insects. Bulletin of the ESA. 31: 14-16. https:// doi.org/10.1093/besa/31.1.14.

Chandra, K., Saini, J. and Gupta, D. (2019a). Insecta: Hymenoptera: Apoidea (Bees). In Fauna of Punjab, State Fauna Series, 23: 1-486. (Published by the Director, Zool. Surv. India, Kolkata). pp. 153-165.

Chandra, K., Singh, L.R.K., Ahmed, I. and Gupta, D. (2019b). Insecta: Hymenoptera. In Fauna of Punjab, State Fauna Series. 23: -486. (Published by the director, Zool. Survey of India, Kolkata). 
Role of Mining Bees (Hymenoptera: Andrenidae) in Pollination Ecology in India: A Review.

Corbet, S.A., Beament. J. and Eisikowitch, D. (1982). Are electrostatic forces involved in pollen transfer? Plant, Cell and Environment. 5: 125-129. https://doi.org/10.1111/13653040. ep11571488.

Corbet, S.A. (1990). Pollination and weather. Israel Journal of Botany. 39: 13-30.

Davis, L.R. and LaBerge, W.E. (1975). The nest biology of the bee Andrena (Ptilandrena) erigeniae Robertson (Hymenoptera: Andrenidae). Illinois Natural History Survey Biological Notes 95: 1-16.https://doi.org/10.5962/bhl.title.15002.

Eickwort, G.C. (1977). Aspects of the nesting biology and descriptions of immature stages of Perdita octomaculata and $P$. halictoides (Hymenoptera: Andrenidae). Journal of the Kansas Entomological Society. 50: 577-599. http:// www.jstor.org/stable/25082987.

Fabricius, J.C. (1775). Systema entomologiae, sistensinsectorum classes, ordines, genera, species adiectissynonymis, locis, descriptionibus, observationibus. Flensburgi and Lipsiae. pp. 391-396.

Franzen, M. and Larsson, M. (2007). Pollen harvesting and reproductive rates in specialized solitary bees. Ann. Zool. Fennici. 44: 405-414.

Giovanetti, M., Luppino, S. and Zola, R. (2006). Preliminary note on the relative frequencies of two bees on wild Brassicaceae: oligolectic Andrena agilissima vs polylactic Apis mellifera. Bulletin of Insectology. 59: 153-156.

Guler, Y. and Sorkun, K. (2010). Analysis of Pollen Collected by Andrena flavipes Panzer (Hymenoptera: Andrenidae) in Sweet Cherry Orchards, Afyonkarahisar Province of Turkey. Hindawi Publishing Corporation, Article ID 160789, 5 pages. DOI:10.1155/2010/160789.

Gusenleitner, F. and Schwarz, M. (2002). WeltweiteCheckliste der Bienengattung Andrena mitBemerkungen and ErganzungenzupalaarktischenArten (Hymenoptera, Apidae andrenidae andrena). Entomofauna, supplement. 10: 1-1280.

Heinrich, B. (1976). Bumblebee foraging and the economics of sociality. American Scientist 64: 384-395. https:// www.jstor.org/stable/27847342

Herrera, C.M. (1995). Floral Biology, Microclimate and Pollination by Ectothermic Bees in an Early- Blooming Herb. Ecological Society of America. 76: 218-228.

Houston, T.F. and Thorp, R.W. (1984). Bionomics of the bee Stenotritusgreavesi and ethological characteristics of Stenotritidae (Hymenoptera). Records of the Western Australian Museum. 11: 375-385.

Jose, S. (2009). Agroforestry for ecosystem services and environmental benefits: An overview. Agrofor. Syst. 76: 1-10. [CrossRef]

Larkin, L. L., Neff, J. L. and Simpson, B.B. (2008). The evolution of a pollen diet: host choice and diet breadth of Andrena bees (Hymenoptera: Andrenidae). Apidologie. 39: 133145. (doi: 10.1051/apido:2007064).

Mallinger, R.E., Bradshaw. J., Varenhorst, A.J. and Prasifka, J.R. (2018). Native solitary bees provide economically significant pollination services to confection sunflowers (Helianthus annuus L.) (Asterales: Asteraceae) grown across the northern Great Plains. J. Econ. Entomol. 112: 40-48. (doi: 10.1093/jee/toy322).
Makkar, G.S., Dey, D. and Chhuneja, P.K. (2016). Mining bee Andrena (Agandrena) agilissima (Hymenoptera: Andrenidae): A new record from India with morphological and molecular notes. Journal of Applied and Natural Science. 8(4): 1775-1778.

Meena, L.K. and Dey. D. (2019a). Annotated Checklist of NonApis Bees of the genus Andrena (Hymenoptera: Andrenidae) from Indian Journal of Entomology. 81(3): 443-452.

Meena, L.K. and Dey, D. (2019b). Taxonomic revisionary studies on subgenus Plastandrena (Andrena: Andrenidae: Hymenoptera) of India. Journal of Entomology and Zoology Studies. 7(1): 1223-1231.

Meidell, O. (1944). Notes on the pollination of Melampyrum pratense and the "honey stealing" of Bumble-bees and bees. Gergens, Museum. 11: 1-12

Michner, C.D. (2000). The Bees of the World. Baltimore and London (The Johns Hopkins University Press). 913 S., 48 Farbfotos und zahir. s/w Illustrationen. ISBN 0-8018-6133-0.

Michner, C.D. (2007). The Bees of the world. Johns Hopkins University Press, Baltimore, Maryland, USA. pp 992.

Müller, A. (1996). Convergent evolution of morphological specializations in Central European bee and honey wasp species as an adaptation to the uptake of pollen from nototribic flowers (Hymenoptera, Apoidea and Masaridae). Biological Journal of the Linnean Society. 57: 235-252. https://doi.org/10.1111/j.1095-8312.1996.tb00311.x.

Michener, C.D. (2007). The Bees of the World. $2^{\text {nd }}$ edition. The Johns Hopkins University Press, Baltimore, 1-913.

Neff, J.L. and Simpson, B.B. (1988). Vibratile pollen- harvesting by Megachilemendica Cresson (Hymenoptera, Megachilidae). Journal of the Kansas Entomological Society. 61: 242244. https://doi.org/https://www.jstor.org/stable/25084993.

Norden, B.B., Krombein, K.V., Deyrup, M.A., Edirisinghe, J.P. (2003). Biology and behaviour of a Seasonally aquatic bee, Perdita (Alloperdita) floridensis Timberlake (Hymenoptera: Andrenidae: Panurginae). Journal of the Kansas Entomological Society. 76: 236-249. https://www. jstor.org /stable/25086110.

Ollerton, j., Winfree, R. and Tarrant, S. (2011). How many flowering plants are pollinated by animals? Oikos. 120: 321-326.

Portman, Z. M., Orr, M.C. and Griswold, T. (2019a). A review and updated classification of pollen gathering behaviour in bees (Hymenoptera, Apoidea). Journal of Hymenoptera Research. 71: 171-208. https://doi.org/10.3897/jhr.71. 32671

Portman, Z.M., Orr, M.C. and Griswold, T. (2019b). Rubbing with the body and/ or scopae. This dataset is made available under the Open Database License (http://opendatacommons.org /licenses/odbl/1.0/). Link: https://doi.org/10.3897/jhr.71. 32671.suppl3

Portman, Z.M., Orr, M.C. and Griswold, T. (2019c). Temporary accumulation of pollen by panurgine bees. This dataset is made available under the Open Database License (http://opendatacommons.org/licenses/odbl/1.0/). Link: https://doi.org/10.3897/jhr.71.32671.suppl8.

Potts, S.G., Imperatriz- Fonseca, V., Ngo, H.T., Aizen, M.A., Biesmeijer, J.C., Breeze, T.D., Dicks, L.V., Garibaldi, L.A., Hill, R., Settele, J. and Vanbergen, A.J. (2016). Safeguarding pollinators and their values to human well-being. Nature. 540: 220-229. 
Role of Mining Bees (Hymenoptera: Andrenidae) in Pollination Ecology in India: A Review.

Russell, A.L., Buchmann, S.L. and Papaj, D.R. (2017). How a generalist bee achieves high efficiency of pollen collection on diverse floral resources. Behavioural Ecology. 28: 9911003. https://doi. org/10.1093/beheco/arx058.

Rust, R.W. and Clement, S.L. (1977). Entomophilous pollination of the self-compatible species Collinsiasparsiflora Fisher and Meyer. Journal of the Kansas Entomological Society. 50: 37-48. https://www.jstor.org/stable/25082899.

Schrottky, C. (1908).Blumen and Insekten in Paraguay. Zeitschrift fur wissenschaftlichelnsek-tenbiologie4: 22-26, 47-52, (3): 73-78. https://biodiversitylibrary.org/page/1199457.

Schoeneberger, M.M., Bentrup, G., Patel-Weynand, T. (2017). Agroforestry: Enhancing Resiliency in U.S. Agricultural landscapes under Changing Conditions; U.S. Department of Agriculture, U.S. Forest Service: Washington, DC, USA.

Tang. J., Quan, Q-M., Chen, J-Z., Wu, T. and Huang, S-Q. (2019). Pollinator effectiveness and importance between female and male mining bee (Andrena). Biol. Lett. 15: 20190479. http://dx.doi.org/10.1098/rsbl.2019.0479.

Tepedino,V.J., Alston, D.G., Bradley, B.A., Toler, T.R. and Griswold, T.L. (2007). Orchard pollination in Capitol Reef National Park, Utah, USA. Honey bees or native bees? Biodivers. Conserv.16: 3083-3094. (DOI: 10.1007/s10531-0079164).
Teppner, H. (2018). The first records of vibratory pollen- collection by bees. Phyton. 57: 129-135. https://doi.org/10.12905/ 0380.phyton57-2018-0129.

Thorp, R.W. (1979). Structural, behavioural and physiological adaptations of bees (Apoidea) for collecting pollen. Annals of the Missouri Botanical Garden. 66: 788-812. https://doi. org/10.2307/2398919.

Thorp, R.W. (2000). The collection of pollen by bees. Plants Systematics and Evolution. 222: 211- 223. https://doi.org/ 10.1007/BF00984103.

Vaknin, Y., Gan- Mor, S., Bechar, A., Ronen, B. and Eisikowitch, D. (2000). The role of electrostatic forces in pollination. Plant Systematics and Evolution 222: 133-142. https://doi.org/ 10.1007/ BF00984099.

Wainwright, C.M. (1978). The floral biology and pollination of two desert lupines. Bulletin of the Torrey Botanical Club. 105: 24-38. https://doi.org/10.2307/2484260.

Zandigiacomo, P., Bernardinelli, I. and Mossenta, M. (2004). "Fenology and plant preference of three species of wild bees (Hymenoptera, Apoidea) in Friuli- Venezia Giulia," in Proceedings of the $1^{\text {st }}$ European Conference of Apidology, Udine, Italy, September 2004. 